\title{
LETTER
}

\section{New Trends in Analytical Chemistry for the Examination and Interpretation of Traces of Crimes}

\author{
Jesus Antonio Velho ${ }^{1,2}$ (iD \\ ${ }^{1}$ Departamento de Química da Faculdade de Filosofia, Ciências e Letras de Ribeirão Preto, Universidade de \\ São Paulo. Av. Bandeirantes, 3900, Ribeirão Preto, SP, 14040-900, Brazil \\ ${ }^{2}$ Instituto Nacional de Criminalística, Polícia Federal, SAIS Quadra 07 Lote 23, 70610-200, Brasília, DF, Brazil
}

Forensic sciences are generally described as the application of the scientific method to the analysis of traces in order to identify the authorship and materiality of a crime (Figure 1). Forensic scientists evaluate different types of materials, and the type of scientific method and techniques employed depend on the questions to be answered within a given context $[1,2]$.

Forensic chemistry is one of the most far-reaching areas within the forensic science field. With the increase in technology and the development of analytical techniques, chemistry has been used more and more to elucidate legal controversies. Therefore, knowledge in chemistry is indispensable to solve crimes [3]. In this letter, the applications of analytical chemistry will be discussed within emerging forensic themes: the determination of the origin of seized drugs (chemical profiling), the investigation of document fraud, and the valuation analysis of pieces of art.

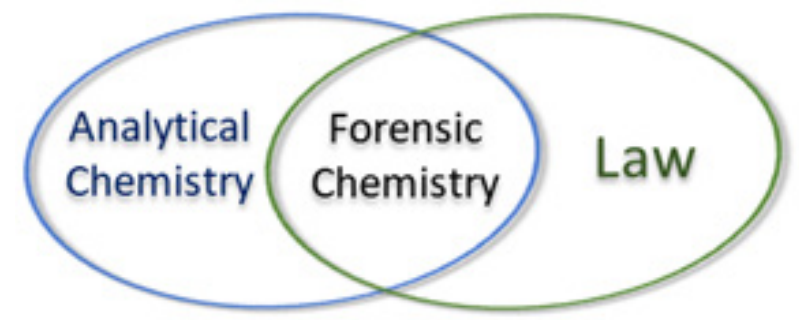

Figure 1. Techniques in analytical chemistry are used for the resolution of legal matters through the forensic sciences.

Chemical profiling consists of a series of chemical analyses that provide the concentration of the components present in the seized drugs, present as major or minor components, or event those present only in trace levels [4]. Using different analytical methods, complex chemical profiles are obtained for each drug sample analyzed, giving these samples a chemical "signature" based on the presence of impurities of natural origin and added diluents/adulterants. Therefore, such studies generate relevant data that make it possible to establish connections between samples and materials of different seizures, classifying them into chemically correlated groups. Through these connections, it is possible to establish specific links among suppliers, drug dealers, and users, designing distribution network patterns and providing subsidies for the identification of the origin of the drug, including its geographical origin [5].

Another striking forensic application of analytical chemistry is age determination and the authenticity of papers and inks. Once an ink is deposited on a support (paper), it is exposed to air, light, and moisture, and the following physical-chemical processes occur: coloration degradation, solvent evaporation, 
and hardening (polymerization) of the resins. These processes have been used in the complex task of determining the absolute or relative (comparative) age of manuscripts on paper. The largest number of publications refer to ballpoint pen inks. Ezcurra and collaborators [6] published a comprehensive review on the dating of paints by modern instrument writers. Analytical paint dating exams essentially consist of quantifying how paint components vary over time [7].

Last but not least, the authentication of pieces of art used as a tool to fight crime is a recent area of activity of analytical chemistry in Brazil. Operation "Lava Jato" shed light on the possibility that criminal use of the art market is a widespread method among agents of corruption and that it is much more complex and structured than previously thought. It is up to criminal experts to determine the authenticity of a piece of art. In general, the analytical investigations are guided by the identification and quantification of substances used in the production of the art piece, using non-destructive methodologies, such as Raman spectroscopy [8].

\section{Acknowledgments}

I dedicate this work to the victims of crimes in Brazil. I would like to thank Dr. Eduardo Geraldo Campos for reviewing this letter.

\section{REFERENCES}

1. Cockbain, E.; Laycock G. Crime Science. In: Oxford Research Encyclopedia of Criminology and Criminal Justice. Oxford University Press, 2017 (https://doi.org/10.1093/acrefore/9780190264079.013.4).

2. Velho, J. A.; Costa, K. A; Damasceno, C. T. M. Locais de Crime. Editora Millennium, Campinas, 2019.

3. Bruni, A. T.; Velho, J. A.; Oliveira, M. F. Fundamentos de Química Forense. Editora Millennium, Campinas, 2019.

4. United Nations Office on Drugs and Crime. Drug Characterization / Impurity Profiling, Background and Concepts, United Nations, New York, 2001.

5. United Nations Office on Drugs and Crime. Methods for Impurity Profiling of Heroin and Cocaine, Laboratory and Scientific Section, United Nations, New York, 2005.

6. Ezcurra, M; Gongora, J. M. G.; Maguregui, I.; Alonso, R. Forensic Sci. Int., 2010, 197 (1-3) pp 1-20 (https://doi.org/10.1016/j.forsciint.2009.11.013).

7. Jones, R. W.; Cody, R. B.; McClelland, J. F. J. Forensic. Sci., 2006, 51 (4), pp 915-918 (https://doi. org/10.1111/j.1556-4029.2006.00162.x).

8. de Faria, D. L. A.; Massabni, A. C. A espectroscopia Raman revelando a química das obras de arte. Conselho Regional de Química da 4ª Região (CRQ IV), Seção Especial da Química Viva, 2019, pp 1-5, São Paulo. Available at: https://www.crq4.org.br/default.php?p=texto.php\&c=quimicaviva_quimica_e_ arte_espec_raman

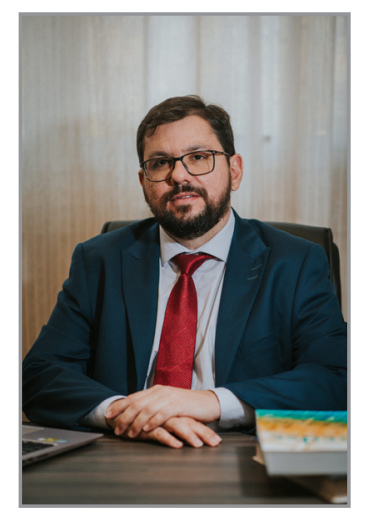

Jesus Antonio Velho has a PhD in pathophysiology from the Faculty of Medicine of the State University of Campinas (UNICAMP) and studied Pharmacy-biochemistry at the State University of Londrina (UEL). He is a Federal Criminal Expert, working in the areas of Crime Scene Analysis, Forensic Chemistry, and Forensic Ballistics. In relation to teaching activities, he is a doctoral professor in the area of criminalistics at the University of São Paulo (USP Ribeirão Preto) and a guest professor at the Federal Police Academy (ANP). He is Director of the Board of the Brazilian Society of Forensic Sciences, 2019/2021. He is a member of the Editorial Board and organizing author of the "Criminalística Premium" series of books by Editora Millennium, in addition to acting as editor of RBC (Revista Brasileira de Criminalística) and RBCP (Revista Brasileira de Ciências Policais).

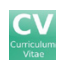

